Marquette University

e-Publications@Marquette

Theology Faculty Research and Publications

Theology, Department of

$1-1-2012$

\title{
Bernard Lonergan and Daniel Berrigan
}

Robert Doran

Marquette University, robert.doran@marquette.edu

Published version. "Bernard Lonergan and Daniel Berrigan," in Faith, Resistance, and the Future: Daniel Berrigan's Challenge to Catholic Social Thought. Eds. James L. Marsh and Anna J. Brown. New York: Fordham University Press, 2012: 119-131. Publisher Link. (C) 2012 Fordham University Press. Used with permission. 


\title{
Bernard Lonergan and Daniel Berrigan
}

\author{
Robert M. Doran, S7
}

Asking what Bernard Lonergan has to do with Daniel Berrigan probably seems to some a transposition to personalities of the age-old question: What does Athens have to do with Jerusalem? Or, in an equally personal transposition, what does Aristotle have to do with Jeremiah? Whether either would approve of what I am about to do in this paper, I do not know. Whether Lonergan approves I will not know until I see him again in the kingdom of God, which I fervently hope will happen and which, I confess, I imagine happening every day. But I may learn earlier whether Berrigan approves or not, and so I proceed in some fear and trembling.

Both were key figures for me during the major transitional period in my life, which occurred between 1969 and 1984 , or between my thirtieth and my forty-fifth birthdays, and so I begin this tribute with some autobiographical reflections.

\section{Autobiograpbical Reflections}

The years just mentioned followed something of a classic pattern of transition from what Carl Jung called the first half of life to the second (where, 
of course, the word "half" is used loosely). Many of the events that Jung speaks about as marking such passages occurred for me during these fifteen years: major archetypal dreams (in some of which both Lonergan and Berrigan were prominent, though never together), significant challenges to both a radical appropriation and an equally radical rejection of elements in my national, cultural, and religious heritage, periods of darkness in which I could not find the way, and an emerging clarity about what I was to do with the remainder of the time God gives me. Never in that period was there a question of being asked to choose between what Lonergan represents and what Berrigan demands, despite the fact that the subsequent course of my life has certainly seemed to be a following more of Lonergan's path than of Berrigan's, a following that did not allow me the time to participate in social movements as much as I may have wanted to do so at times. Only in the fact that Dan and I both spent a great deal of time and energy with persons living with, and dying from, the effects of HIV infection and AIDS did our work have much in common, and even then we were doing this work in different cities-he in New York, I in Toronto-and we were not working together in this ministry. ${ }^{1}$ But from the time of the major turning point in my life to the present both Lonergan and Berrigan have been figurae, as it were, of something that I had to integrate as best I could into my personal religious stance if I was to have any hope of living peaceably with myself. Never did I experience a dialectical conflict between what one stood for and what another claimed of me. As I look back on my life now, I realize that at every point, most of the time, without adverting explicitly to either of these Jesuit brothers as such, every step that I took had to satisfy what each of them represented to me or there would be something wrong with my choice. Whether I succeeded in such a delicate integration or not is ultimately God's judgment to make, and I will not know for sure until that judgment is in.

What bound these figurae together almost from the beginning of my attraction to them? The expression that comes to mind is "their radical resistance to decadence and corruption." In Berrigan's case we are clear about both the resistance and what has been resisted. In Lonergan's case the issue is perhaps not as clearly defined. But I once heard the great work Insight (in my view the principal philosophical work of the twentieth century) referred to as a work of resistance against the sterility of some very influential neo-Thomist appropriations of Aquinas, and immediately I recognized in that comment my own appreciation of Lonergan's significance. Interestingly enough, for Eric Voegelin, one of the great commentators on the meaning of "Athens," of Greek philosophy, but also on Israelite 
prophecy, resistance to corruption is also what Plato and Aristotle, on the one hand, and the great prophets, on the other, had in common. ${ }^{2}$

But I must add that in the instances of Lonergan and Berrigan, as in Israel and Greece, resistance alone is not a sufficient explanation of a life's deeds. The resistance was in each case driven by a vocation to promote an alternative, and I have no doubt that with Lonergan and Berrigan the vocation was from the God to whom each had given his life as a result of experiences rooted in the Spiritual Exercises of St. Ignatius Loyola.

At any rate, the personal journey of which I speak began with the Vietnam War. While I was a doctoral student at Marquette University in 1969, I was asked by the university to take a two-year break from my studies in order to become the first director of a new program in Campus Ministry. While the office of Campus Ministry did not open until August 1970, those of us who were hired to staff that office became engaged with student protests that followed the murders at Kent State University in the spring of that year. It quickly became obvious to us that we had our work cut out for us, since some of the protests and protesters were on the verge of becoming violent, and we believed that our efforts had to model and encourage a different way to taking issue with what we believed was a national tragedy. It was an entirely new challenge for me, one that I was probably not quite ready to assume, and undoubtedly one at which, in the last analysis, I failed. During these years I often reflected on Fr Pedro Arrupe's reported comments to some young Jesuits who were working on the edge with issues of poverty and justice: "Be ready to accept failure, while still acknowledging that what you are doing is God's work. For you will fail."

My efforts in my two years as director of Campus Ministry included advocacy on peace issues, draft counseling, and antiwar activities, and this part of our service to the university met with greater resistance than did the more sacramental dimensions of our work (except when these incorporated the advocacy, which they often did). While in my studies I was already a thoroughly committed student of Lonergan, throughout this period it was the figure of Daniel Berrigan that was more prominent in my thoughts and in my psyche. Berrigan was quoted more than anyone else in the homilies that I gave on a regular basis during these years. He was present in my dreams on a number of occasions, beginning during these two years but also for several years afterward, always as a friendly figure but also always standing precisely for what we all know he represents. I took away from these experiences, and especially from Berrigan's presence in these dreams, a deep-seated affective consolidation of his message as something that had 
to remain with me no matter what else I might do in the future. Again, the extent to which I have actually allowed this to happen is God's judgment to make.

On my return to doctoral studies in 1972 , I addressed in study and writing a number of the issues that had already engaged my attention in the years of active social involvement. By this time in his own development, Lonergan had made the theme of conversion central in his work, so central that today people who know little else about Lonergan know that conversion is at the heart of his work. He had also returned to the study of economics, driven by deep concerns for the transformation of economic systems so that they could deliver justice.

My own reflection on what conversion entailed, however, took me in directions that were not yet explicit in Lonergan's work, directions that had been opened up, however, by my recent experiences and struggles. While Lonergan was eventually to approve these directions, the initial steps had to be taken alone and, like Lonergan's work in Insigbt, were conceived in my mind as entailing resistance to an intellectual neglect: this time a neglect of the energic flow of sensations, memories, images, emotions, conations, bodily movements, spontaneous responses to persons and situations, associations. In a homily marking the beginning of the Campus Ministry program at Marquette I quoted something that Berrigan had written in an open letter to the Jesuits, published, I believe, in National Catbolic Reporter, to the effect that, until the individual changes, nothing changes. ${ }^{3}$ And while I had always recognized that this emphasis was entirely congruent with Lonergan's notion of conversion, I now was beginning to understand that the change demanded could assume dimensions beyond those that are explicit in Lonergan's writings. For what is it that drives and impels the forces of death against which Berrigan has set all his might and energy? From a theological point of view, it is the sin of the world, what good Scholastic theology would have called peccatum originale originatum (originated original sin), but precisely as this sin of the world is objectified in the social machinery, including military technology, characteristic of the imperial society into which American children are born, and in which they are raised, socialized, acculturated, educated. So much of this distortion, this creation of a false "second reality," takes place at an elemental psychic level without the children having anything to do with the reception of a grossly deviated set, indeed scale, of values. Surely the turning about, the repudiation of what has been, that is part of any genuine conversion process must include tapping into this psychic reservoir and allowing it to be transformed by God's grace. 
And so I developed the notion of a psychic dimension to conversion, to complement and accompany the intellectual, moral, and religious dimensions that Lonergan had highlighted. The psychic conversion that I was talking about was closely aligned to the social concerns that Berrigan represented, for it is in the energic flow of psychic responses that our values first come to be set for us, before we have had any say in the matter, and in the case of Americans (as of course for everyone else) this means universally a mixture of good and evil and often a preponderance of the latter. The conversion demanded of this country in particular cuts very deep, much deeper than we are prepared to admit, as Berrigan has never ceased to remind us. It is the conversion of an entire scale of values from an imperialistic distortion to the fostering of genuine community on a global scale.

I pursued in my doctoral dissertation the connection of the psychic conversion that I was promoting with Lonergan's intellectual, moral, and religious conversion, and, to my great delight and joy, found that Lonergan was heartily supportive of what I was attempting to do. He expressed his enthusiasm to me personally in the fall of 1973 , and I can say that in many ways my life has never been the same since then. The path was set, the vocation within a vocation was determined, and that path and vocation were to be intellectual and academic. That much was clear by the time I completed doctoral studies in 1975 , though it was further consolidated shortly after I arrived in Toronto in I979, when Lonergan called me from Boston and asked me to be one of the executors of his literary estate. That request has led me eventually to assuming responsibility, for the publication of his collected works, for the first twenty years of the project together with Frederick E. Crowe: something that, shortly before he died in 1984 , I promised him I would do. ${ }^{4}$ That promise and the responsibility it demands to secure Lonergan's legacy as best I can have determined the course of my life ever since and will continue to do so until I can work no more.

At the time of Lonergan's death Fred Crowe and I had already succeeded in getting the University of Toronto Press interested in publishing Lonergan's collected works, and we were busy planning for the establishment of the Lonergan Research Institute in Toronto, partly for the sake of seeing to the production of the Collected Works. While the latter institutional venture did not fulfill the hopes that Fred and I had for it, the work that the Institute began - preserving, promoting, developing, and implementing Lonergan's work-continues in other venues and under other auspices. If Daniel Berrigan has experienced that a prophet is not without honor except among his own people, Lonergan knew the same fate, and unfortunately it has continued after his death. 
I wish to emphasize that through all of these transformative and determinative events it remained clear to me that $\mathrm{I}$ had to take with me on that path the Berrigan influence that had touched my inner life just as deeply as had Lonergan's writings, or else the very pursuit of the path that Lonergan offered to me, in fact gave to me, would not be genuine.

Next, I will discuss the two ways in which I hope Berrigan accompanied Lonergan in my own life as that life moved forward from the point just narrated. These two ways had to do with justice for the poor and nonviolent resistance to evil. I would like to articulate how these commitments have informed my work over the past thirty-plus years, and offer that in tribute to Daniel Berrigan, poor token though it may be of my appreciation for his courage, strength, and inspiration.

\section{The Option for the Poor}

How are we to speak today about what Jesus proclaimed as the kingdom or reign of God in human society and history? That was the issue that preoccupied me in the 1980 os when I spent a good decade writing what became Theology and the Dialectics of History. ${ }^{5}$ I took with me into this decade the commitments and orientations that both Lonergan and Berrigan stood for, and a quite central obligation that I put on myself in writing this book was to make sure that each of these orientations was acknowledged in it.

Theology and the Dialectics of History, a book that I admit is too long, is an effort to provide at least some of the basic categories that might be useful in our time to speak about the reality that Jesus proclaimed in his own Jewish context. The book is structured around a vast and complicated development of a very simple schema of a scale of values that Lonergan presents in Method in Theology. ${ }^{6}$ And the book emphasizes that it is the role of the Church, as the community of the servant of God, to evoke the integral functioning of that normative scale. ${ }^{7}$

The scale itself is a function of Lonergan's complication of his own earlier schema of the so-called "levels" of intentional consciousness: presentations, understanding, judgment, and decisions. For to each of these dimensions of intentional consciousness there corresponds an isomorphic component of the human good: vital values to presentations, the social good of order to understanding, culture to judgment, and personal authenticity to decision. And as the structure of intentional consciousness is not a closed structure but one that is open to the fulfillment that only God's love poured out in our hearts by the Holy Spirit who is given us (Romans 5.5) 
can provide, so the socio-historical unfolding of the normative scale of values is open to and receptive of the communication of God's grace and God's message. Thus a scale of values is established that proceeds "from below" from vital to social to cultural to personal to religious values, and "from above" from the gift of God's grace to personal authenticity, from personal authenticity to cultural transformation, from cultural transformation to the justice of the social order, and from social justice to the equitable distribution of vital goods to the entire community. While the scale enables us to develop a notion of collective responsibility (something that Lonergan himself called for $^{8}$ ), I call attention here to the role of the conversion of the individual, the level of personal value. Just as Berrigan once stressed in writing to his Jesuit brothers that until the individual changes, nothing changes, so Lonergan emphasizes that personal conversion is at the heart of social and historical transformation. But I call attention as well to the obvious fact that for each of them personal conversion is not an end in itself but the result perhaps of a series of withdrawals for the sake of a return to caring for the integrity of cultural meanings, the justice of the social order, and the equitable availability of vital goods.

There is a schematic neatness to the scale that probably has led some people to think of it as little more than a model, but that criticism would be justified only if the base from which the scale is constructed is itself nothing more than a model. There is, of course, basically nothing wrong with models. As Lonergan stresses, they may be very helpful in the task of actually describing or explaining reality. ${ }^{9}$ But they are not themselves such descriptions or explanations. But if the base of the scheme lies in the invariant structure of conscious intentionality as it moves from presentations to understanding, from understanding to judgment, and from judgment to decision, or in the other direction from falling in love with God to a transvaluation of values, from that change to a new cognitive appreciation of the world, and from that eye of love to action on behalf of justice, then we are talking about more than a model. And such is indeed the base of the normative scale of values.

This is probably not the appropriate place to venture into the further complications of the scale that are due to the dialectical structure of personal, cultural, and social values, except, of course, to stress that these dialectical structures are distorted by the same sin of the world, the same "originated original sin," that, writ large (very large indeed), constitutes by default the social and military monstrosities which so much of Daniel Berrigan's life has committed to calling by its true names: idolatry, lust for power. Thus, the book constructs and amplifies the notion of the scale of 
values in direct antithesis to the distortions wrought by imperialistic and totalitarian ambitions.

The individual aspects are, of course, not neglected. The scale is a function of the affective component of each of the levels of intentional consciousness, of feeling's response to possible values. The criterion of the scale is the degree of self-transcendence to which we are carried in our responses. And the deviation of that affective self-transcendence is a function of the wounded psychic structures-wounded by forces beyond the individual's control at the time of the wounding - that my notion of psychic conversion was meant to tease out as the individual takes on the task of what Lonergan calls self-appropriation.

But despite these emphases on the healing and conversion of the individual, I argue in Theology and the Dialectics of History that a full-scale presentation of the scale of values might constitute something of a transcendental argument for the liberation emphases on the preferential option for the poor, emphases which, however begrudgingly at times, official church teaching has acknowledged. For problems in the equitable distribution of vital goods can be resolved in justice only by transformations in social structures, in technologies, economies, polities, and spontaneous interrelatedness; and these transformations demand changes in the meanings and values by which people live, which changes in turn are a function of the conversion of the person to authentic self-transcendence-until the individual changes, nothing changes. But that personal transformation itself depends on the gift of God's grace, which is required for consistent self-transcendent performance affectively, intellectually, morally, and politically. Conversely, then, God's gift of love effects personal transformation; such conversion shows itself in the transformation of the meanings and values constitutive of a culture; this transformation alone guarantees the justice of the social order, which itself is required for the equitable distribution of the earth's vital goods. The so-called transcendental structure of presentations, understanding, judging, and deciding has been complicated to yield a scale of values that itself provides the church with a firm validation of the liberation insights into the preferential option for the poor. Perhaps it also provides a framework within which contemporary theology can speak of the reign of God, with some hope of continuity with what Jesus meant when he called for a radical conversion in his own context. Explicit consideration is given to the distortions of the scale found in Western imperialism and in what at the time I wrote the book was Soviet totalitarianism. Joseph Schumpter's definition of imperialism as "the objectless disposition on the part of a state to unlimited forcible 
expansion" ${ }^{\circ}$ was developed in the context of the distortion that such a disposition causes in the entire scale of values.

\section{Violence and Religion}

I turn now to considerations that emerges from a closer inspection of the structure and dynamics of genuine religion. "Religious values" as they function within the scale of values will upset and distort the entire scale in the direction of deviation if in fact they really are religious aberrations. And religious aberration is manifest in the involvement of religion with the structures and mechanisms of violence. There is no going back, I both hope and fear at the same time, on René Girard's emphasis on the violent nature of most religion (including a great deal of historical Christianity). We can only move forward, to face the delicate and difficult questions regarding what these insights will mean for the church and its institutions in the twenty-first century, and especially regarding its relations with the other religions of humankind.

In my understanding of a quite complex set of conceptual relations, Girard's work connects with Lonergan's precisely through the notion of psychic conversion, while the latter notion gains from Girard a greater precision than I was able to give it previously. In my previous efforts, I contrasted with other psychological efforts, most notably those of C. G. Jung, the depth-psychological system that emerges when one understands the human psyche-at the empirical level, the flow of sensations, images, emotions, conations, associations, conscious bodily movements, spontaneous intersubjective responses - in light of Lonergan's analysis of intentional consciousness. While it is true that this contrast already sets the stage for a reorientation of depth-psychological thinking and practice on the basis of foundations that ultimately are theological-religious, moral, and intellectual conversion - still, there is a greater precision to be gained by understanding the psyche in Girard's terms. Let me explain.

In his mammoth work on the systematics of the Trinity, Lonergan makes a distinction that $I$ have found helpful not only in explaining what I mean by psychic conversion and how I understand its relation to Lonergan's work but also in introducing within a Lonergan-inspired framework the dimensions that Girard brings to the fore. He writes:

we are conscious in two ways: in one way, through our sensibility, we undergo rather passively what we sense and imagine, our desires and fears, our delights and sorrows, our joys and sadness; in another way, 
through our intellectuality, we are more active when we consciously inquire in order to understand, understand in order to utter a word, weigh evidence in order to judge, deliberate in order to choose, and exercise our will in order to act. ${ }^{I I}$

My previous efforts at integrating depth-psychological with intentionality analysis and at reorienting the former in the light of the latter stayed within the kind of framework that this quotation establishes: a framework that, despite the social motivation instrumental in the original development of the notion of psychic conversion, is still highly individual in character. What Girard helped me to recognize more clearly is that the first "way of being conscious" that Lonergan specifies here is precisely not at first and for the most part exclusively individual but, in Girard's term, interdividual, a function of the priority of the social over the individual. Girard's notion of the interdividual gives us a purchase on the theology of original sin that may prove to be epochal. Lonergan speaks of bias and is quick to acknowledge, especially in what he says about dramatic and group bias, the presence of a psychic component that distorts and derails the quest for meaning and truth and goodness. But for Girard, the dramatic or emotional or psychic component of bias is a function of the mimetic character of human desire. For Girard, what occurs at the level of the passive undergoing of our desires and fears, our delights and sorrows, our joys and sadness, is mimetic. Many, perhaps most, of our desires are not autonomous or innate, but copied from others. "If I desire a particular object, I do not covet it on its own merits but because I 'mimic,' or imitate, the desire of someone I have chosen as a model. That person-whether real or imaginary, legendary or historical — becomes the mediator of my desire, and the relationship in which I am involved is essentially 'triangular.' "I2

Now what Girard calls the "object" can be located at or related to any of the levels of value in the scale of values. There is mimetic rivalry in the academy and the Church, just as there is in the wider society. Mimesis in itself (or in the abstract) is neutral. But acquisitive or appropriative mimesis leads to violence, whether overt or covert. Acquisitive mimesis is focused on the object because of the model or mediator, but eventually the object all but drops out of sight, and the subject becomes obsessed-and it is indeed an obsession-almost exclusively with the model or mediator. Mimesis then becomes conflictual. Conflictual memesis is contagious. It can infect a community, an institution, a governing body, a religious establishment, and it can endanger the welfare and even the survival of the groups if affects, at least until the focus turns on one individual or group, 
namely, the scapegoat, whose immolation, exclusion, or expulsion brings a precarious peace. The victimization mechanism is the origin of a deviated transcendence that characterizes a great deal of human religion.

Such is the basic schema that governs much of Girard's thinking. According to Girard, however, there is a progressive revelation in the biblical texts of this set of mimetic mechanisms, which finally become unveiled for all to see-and so lose their power-in the crucifixion of Jesus. ${ }^{13}$ This liberation is one element of the salvation that the cross and redemption of Jesus effect. Perhaps through Girard's help we will come to see it as a central element in soteriology, and perhaps also we will see mimetic violence as the basic element in the sin of the world. The original temptation is represented in the Book of Genesis as awakening a desire to be like God (or like gods). The first murder recorded in the bible is prompted by mimetic rivalry. The Gospels of Mark and Matthew tell us that Pilate knew that the reason the chief priests had handed Jesus over was out of jealousy (Mark 15:10, Matthew 27:18) Lonergan was on the same track, I believe, without having studied Girard's work, and I think this is reflected especially in his recognition of the importance of Max Scheler's book Ressentiment. ${ }^{14}$ And if the biblical writings reflect a progressive revelation of the mimetic mechanism and of the deviated transcendence, the false religion, that it inspires, perhaps it is also true to say that history since then manifests a terribly slow appropriation of this revelation. Are we poised finally to make it our own in our time? Girard hopes so. The origin of the hope is the resurrection of Jesus: "The Resurrection is not only a miracle, a prodigious transgression of natural laws. It is the spectacular sign of the entrance into the world of a power superior to violent contagion. By contrast to the latter it is a power not at all hallucinatory or deceptive. Far from deceiving the disciples, it enables them to recognize what they had not recognized before and to reproach themselves for their pathetic flight in the preceding days. They acknowledge the guilt of their participation in the violent contagion that murdered their master." ${ }^{5}$

But Girard's hope is grounded also in the other divine mission, that of the Spirit.

What is this power that triumphs over mimetic violence? The Gospels respond that it is the Spirit of God, the third person of the Trinity, the Holy Spirit ... In the Gospel of John the name given to this Spirit admirably describes the power that tears the disciples away from this all-powerful contagion: the Paraclete ... The principal meaning of parakletos is "lawyer for the defense," "defender of the accused" ... 
The Spirit enlightens the persecutors concerning their acts of persecution. The Spirit discloses to individuals the literal truth of what Jesus said during his crucifixion: "They don't know what they are doing" . . . The birth of Christianity is a victory of the Paraclete over his opposite, Satan, whose name originally means "accuser before a tribunal," that is, the one responsible for proving the guilt of the defendants. ${ }^{16}$

Because of the gift of the Spirit, there is another kind of mimesis. It is found in Jesus's announcement of the reign of God, where it becomes an imitation of the Father that Jesus commands when he says, "You must therefore be perfect as your heavenly Father is perfect" (Matthew 5:48). What he means was explained several verses earlier: "Love your enemies and pray for those who persecute you; in this way you will be children of your Father in heaven, for he causes his sun to rise on the bad as well as the good, and his rain to fall on honest and dishonest alike" (Matthew $5: 44-45)$.

The imitation of God that Jesus means when he says, "You must therefore be perfect as your heavenly Father is perfect" (Matthew 5:48), Lonergan anticipates when he refers to sanctifying grace and charity as created imitations, respectively, of the divine relations of active and passive spiration. ${ }^{17}$ Active spiration is the Father and the Son as together they "breathe" the Holy Spirit. Passive spiration is the Holy Spirit thus breathed. In Lonergan's theological anthropology, being in love without restrictions, qualifications, conditions, reservations (which, he insists, is the meaning of the more metaphysical term 'sanctifying grace') is a created participation in active spiration, while the acts of loving that flow from this entitative elevation coalesce into a habit of charity that is the created participation in passive spiration. But a created participation in active spiration is precisely an imitation of the Father and the Son, and if imitating the Father means what Jesus says it means, it is set directly over against the deviated transcendence that is rooted in acquisitive and conflictual mimesis. God creates in grace the imitation, the mimesis, that is truly life-giving, and that imitation, that mimesis, is an imitation of, in fact even a created participation in, the divine relations themselves. Grace, too, is radically interdividual, and the founding subjects of the relations that it establishes are those divine subjects that themselves are eternal relations of self-transcendent love.

I am currently writing a volume in systematic theology entitled The Trinity in History. In its present draft form there appears the following:

"The Trinity in History" would presumably have a great deal to do and say about the problems of violence, and the collusion of religion in 
violence, that are at the heart of Girard's work. Relating the four-point hypothesis [Lonergan's hypothesis about created imitations of the divine relations] to Girard's mimetic theory from the outset of our endeavors is crucial for unpacking on the level of our time the meaning of the reign of God, and only such unpacking will keep our systematic theology in some sort of continuity with the mission of the incarnate Word in history.

The upshot of the present essay is that Bernard Lonergan and Daniel Berrigan have both spoken something of the truth about this God who manifested Godself incarnate in Jesus of Nazareth and who continues to break the power of violence through the gift of the Holy Spirit? They had different vocations within the same religious order, which itself serves God in the universal Church, but to the extent that they both spoke a true word about the God whom they have served, and especially to the extent that speaking that true word was an act of resistance against the forgetfulness that leads us to not know what we are doing, their vocations cannot be in dialectical conflict. ${ }^{18}$ I can only hope that stating this conviction as best I can in the present context is something of small tribute to Daniel Berrigan and that he will accept it in the spirit in which it is offered. 